$\xi=-1$

\title{
The Determinants of User Behavior of Computer Based Trans- action Processing Systems: The Case of Minimarket Employees in Padang, Indonesia
}

\author{
Yuhelmi $^{*}$, Surya Dharma ${ }^{2}$, Mery Trianita $^{3}$, Listiana Sri Mulatsih $^{4}$ \\ 1,2,3,4 Lecturer of Study Program of Management, Bung Hatta University, Padang City \\ *Corresponding author E-mail: yuhelmis@yahoo.co.id
}

\begin{abstract}
This study was aimed to investigate the determinants of actual use of computer based transaction processing system among employees in minimarkets in Padang, Indonesia. In addition to Perceived ease of use and perceived usefulness which are the basic models of Technology Acceptance Model (TAM), Subjective norm was conceptualized as an external variable that affecting Technology Acceptance among users of transaction processing system. In total, 246 employees participated in this study. The results show that the perceived ease of use positively affects Perceived Usefulness and Attitude. Furthermore, perceived usefulness and subjective norm have positively affected on Attitude. Likewise Attitude has positively affected on Actual Use. This study reveals that employees tend to comply the peers' opinion on using transaction processing system. For future research is expected to expand the TAM model by adding external variables and individual characteristics as a moderator variable
\end{abstract}

Keywords: Technology Acceptance Model (TAM), User Behavior of Computer Based Transaction Processing System

\section{Introduction}

In the city of Padang, Indonesia, minimarkets are experiencing a faster growth, because the government strongly supports local entrepreneurs to build minimarket in this area. Along with the development of technology, local entrepreneurs have to make adjustments with the advancement of technologies used in the operational activity of minimarket. The need for information technology becomes very important for the minimarket to improve performance in order to meet users' satisfaction and excellent service to consumers. One of the technologies used to help minimarket operations is computer-based transaction processing system which is a process of doing things using a computer designed to process, store data and produce output. One of the outputs produced is information used for decision making (such as information on the amount of inventory, sales trends of each type of product, the amount of sales per period, and the amount of profit earned). The transaction processing system will help to streamline the work in terms of time, effort, and cost to obtain optimum results (1-2).

A recent study by Yuhelmi, Surya and Mery (2017) show that $85.6 \%$ of 97 minimarkets have purchased (or owned) computerbased transaction processing system However, the utilization rate of computer based transaction processing system among employees in these minimarket is still low. Although the minimarkets are equipped with a transaction processing system, the study shows that $94.8 \%$ of minimarkets still use physical count for inventory information and $56.6 \%$ of minimarkets use manual record system in the planning of ordering goods. The phenomenon of low utilization level of computer-based transaction processing system in minimarket represent an important issue to be addressed.
Davis (3) developed technology acceptance model known as the Technology Acceptance Model (TAM) that explains user behavior, i.e. perceived usefulness and perceived ease of use have effect on attitude toward Behavioral intention to use. Perceived usefulness is a level where one believes that the use of system will improve its performance, whereas perceived ease of use is the rate at which one believes that using the system is easier (4). So if the user feels the system useful and easy to use, it will affect the attitude in using the system.

Although previous research has found TAM to be a parsimonious and robust model, TAM only employs two user beliefs (perceived usefulness and perceived ease of use) to explain technology acceptance. However, Schierz et al.(5) believe that subjective norms become important in influencing user attitudes in using transaction processing systems. Taylor (6) stated the user behavior in work is influenced by the other people's behavior surrounding them (e.g. Colleagues, superiors, the organization as a whole). Therefore, this study aims to investigate the determinants of actual use of computer-based transaction processing system with the subjective norm as an external variables, perceived ease of use and perceived usefulness that influencing to attitude and actual use.

\section{Literature Review}

\subsection{Theory of of Technology Acceptance Model (TAM)}

Various behavioral theories have been proposed by expert researchers both in the field of social psychology and information systems. Davis (3) conducted research on the acceptance of electronic mail systems and XEDIT using the Technology Acceptance Model (TAM) developed from the Theory of Reasoned Action 
(TRA) model from Ajzen (7). The results found that perceived usefulness and perceived ease of use had a positive effect on selfpredicted use. Davis et al (4) conducted a study (figure 1) using MBA students as respondents, to analyze the use of word processing after 1 (one) hour and after 14 weeks. The results showed that perceived usefulness had positive effect on the use of word processing, whereas perceived usefulness only had a positive effect after 1 hour and had no effect after 14 weeks.

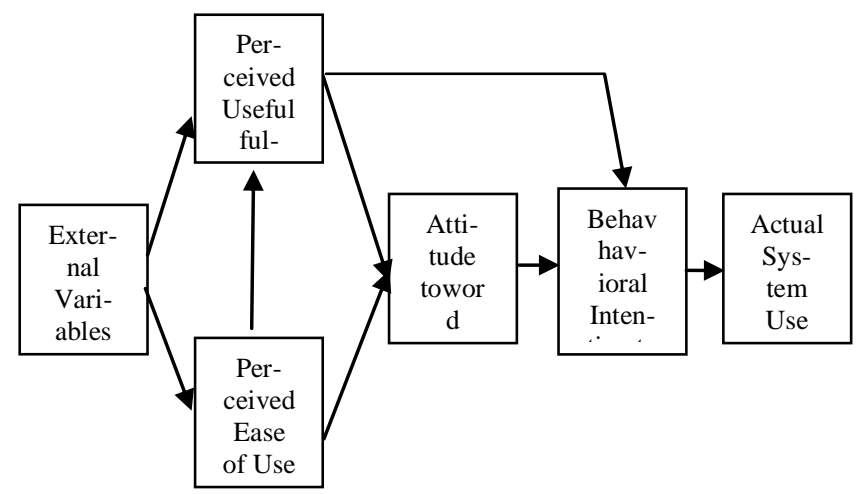

Figure 1. Technology Acceptance Model (TAM)

Source : Davis et al. (4)

Venkatesh (8) has been doing extensions an original TAM called TAM2. It was developed on the basis of an antecedent extension of perceived usefulness. Most empirical testing of TAM (9-11) perceived usefulness, is consistent and strong to determine behavior intention. TAM2 incorporates additional theoretical constructs spanning social influence process (subjective norm, voluntariness, and image) and cognitive instrumental process (job relevance, output quality, result demonstrability, and Perceived ease of use). The entry of subjective norms in the model influences the behavior intention directly and through Perceived usefulness when mandatory settings.

Venkatesh \& Bala (12) developed the TAM model to be TAM3. In his research there are 5 external variables (subjective norm, image, job relevance, output quality, and result demontrability) that affect Perceived Usefulness and 6 other factors (computer self efficacy, Perception of external control, computer anxiety, computer playfulness, perceived enjoyment and objective usability) that affect perceived ease of use and 2 moderating variables (experience and Voluntariness). The results find subjective norm of positively effect against perceived usefulness, but has no effect against the perceived ease of use and behavior intention.

\subsection{Research Model}

This research model modifies the TAM model. This model does not use behavior intention, but directly see the effect of attitude towards the actual use by considering that subject of research is the person who is working with a transaction processing system in his work in the minimarket. The research model can be seen in Figure 2.

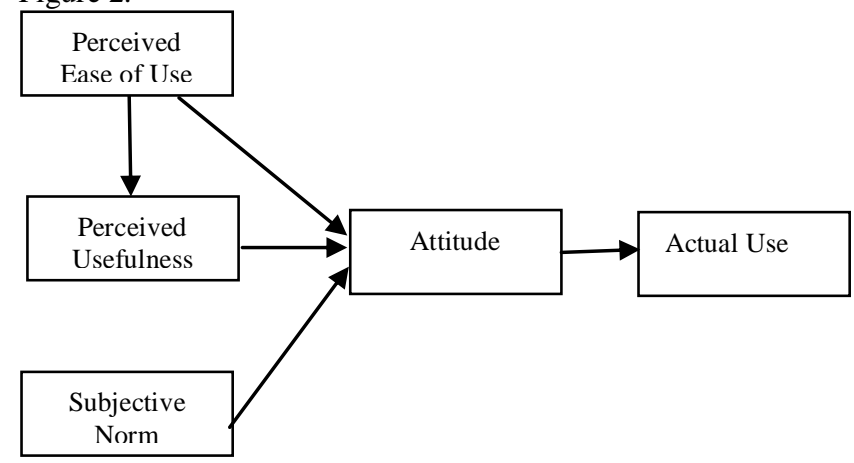

Figure 2. Research Model

\section{Hypotheses Development}

The effect of perceived ease of use against perceived usefulness and attitude

Perceived ease of use defined a person's trustworthiness towards the ease of use of information technology (12). Using technology can be easier if the information system program is designed in such a way that it is considered to be easy to operate, can be understood easily, So if the user, of information technology system feels easy to use the system, he/she will feel the benefits of using the system. Some research found that perceived ease of use has a positive effect on perceived usefulness (9,13-14). Perceived ease of use from the use of Information Technology can also influence attitude toward to use $(11,15-16)$. The easier information technology systems to use, the happier users to use it. The works become more interesting and users like to use it. Based on previous concepts and research, it can be formulated as follows:

H1: Perceived ease of use is positively related to perceived usefulness.

H2: Perceived ease of use is positively related to attitude

\subsection{The influence of perceived usefulness on attitude}

Perceived usefulness is a belief that the use of information technology systems provides significant benefits in helping their work. The perceived usefulness can be improved performance, more efficient and the process are simpler (17). Perceived usefulness is also felt when the use of information technology systems will facilitate the work and increase work quality (4). The use of computers and the Internet will speed up the work (18). Perceived Usefulness has a strong significant effect on the attitude of the use of information technology $(3,10)$. Darsono (15) found Performance Expectancy or perceived usefulness have a positive effect on attitude. Similar results were also found by $(11,19)$. So the hypothesis could be formulated:

H3: Perceived Usefulness affects Attitude positively

\subsection{The influence of Subjective norm to attitude}

Subjective norm is a user perception of whether other important people feel they should engage in behavior $(7,20)$. Subjective norm of positive effect against the attitude of consumer acceptance of mobile payment services (5). Earlier researchers more researching on the influence of subjective norms (social influence) against Behavior Intention. But in terms of a model of this research, subjective norms influence on Attitude. If the user system supported by a colleague, superiors and the Organization in using computer-based transaction processing system, then it will affect the attitude of the users in using the system. The user is going to be like to work with the system. Therefore, hypotheses can be formulated:

H4: Subjective norm positively affects Attitude

\subsection{The influence of attitude to actual use}

Attitude is positive or negative feeling towards the use of information technology. If users feel happy and like to use the system, it will always use the system at work. From some researchers who use TAM model, they found positive attitude influence on Behavior Intention (21). In this study, attitude directly affects the actual Use, in the sense that if users are happy to use the system, he/she will always use the system at work, even the work will depend on the use of the system. Then the hypothesis:

H5: Attitude has a positive effect on actual use 


\section{Methods}

\subsection{Participants}

This research was conducted at minimarket in 10 sub-districts of Padang City Indonesia, which have implemented computer-based transaction processing with Minimarket employees as respondents. Sampling technique is a purposive sampling technique that is based on certain purpose with specified sample criterion. The sample criteria are minimarket, employees who work using computer-based application systems such as cashiers, administrative staffs, warehouse staffs, supervisors and minimarket managers.

\subsection{Data Collection}

The data used are primary data collected through the distribution of questionnaires to respondents. For each item was measured using a 5-point Linkert scale, ranging from 1 (strongly disagree) to 5 (strongly agree).". From the 260 questionnaires distributed to respondents, returned 251 questionnaires were returned, 5 of which could not be processed because they were not filled completely. Thus, the usable number of returned questionnaires is 246 .

\subsection{Data Analysis}

Before conducting hypothesis testing, tested the instrument with validity and Reliability. For validity test, We used Pricipal Componen Analysis with loading factor. The statement is valid if loading factor $\geq 0,4$ (22). Reliability test used Croanbach Alpha with criteria if Croanbach Alpha $\geq 0.7$ (22) then constructs is reliable. This study uses the program STATA version 12

\section{Results and Discussion}

\subsection{Respondent's Profile}

Based on respondent characteristics in table 1, it turns out that employees who work by using computer based - transaction processing system is more Female (78\%) than Male (22\%). In terms of education, the dominant respondents are high school graduates, $82.1 \%$, Bachelor (S1) 11\%, D3 education, $4.9 \%$ and there are still $1.2 \%$ of junior educated staff. While from work field more work as cashier $(55,7 \%)$, as a supervisor or admin counted $21,5 \%$. Beside that, we also found servant or clerk who at times act as cashier as much as $12,2 \%$, the rest are managers / owners and warehouse staffs. $61 \%$ of employees who work using an application system have no prior knowledge in computer and only $39 \%$ have prior knowledge in computer. This indicates that many Minimarket owners do not pay attention to educational background in accepting employees, because owners believe the application system used is easy to be taught to employees, so special education is not needed

Table 1. Respondents' profile

\begin{tabular}{|l|l|r|r|}
\hline Description & Description & Frequency & Percent \\
\hline Gender & Male & 54 & 22 \\
\hline & Female & 192 & 78 \\
\hline Education & Junior High & 3 & 1.2 \\
\hline & Senior High & 202 & 82.1 \\
\hline & Diploma 3 & 12 & 4.9 \\
\hline & Bachelor & 27 & 11.0 \\
\hline & Others & 2 & 0.8 \\
\hline Occupation & Cashier & 137 & 55.7 \\
\hline & Warehouse staff & 13 & 5.3 \\
\hline & Clerk & 30 & 12.2 \\
\hline & Supervisor & 53 & 21.5 \\
\hline & Manager/Owner & 13 & 5.3 \\
\hline Prior Knowledge in Computer & Yes & 96 & 39 \\
\hline & No & 150 & 61 \\
\hline
\end{tabular}

\subsection{Validity and Reliability Test}

Validity test results by using confirmatory factor analysis showed that all statement items on each constructing element are valid as shown in Table 2. All loading factor of each item is more than or equal to 0.4. Reliability Test of each construct used Cronbach's Alpha. The result of all constructs has high reliability with values above 0.7 . It shows a high degree of consistency of constructs.

Table 2. Validity and Reliability Test

\begin{tabular}{|c|c|c|}
\hline Item Pernyataan & $\begin{array}{c}\text { Loading } \\
\text { Factor }\end{array}$ & Reliability \\
\hline \multicolumn{3}{|l|}{ Perceive ease of use (PEU) } \\
\hline PEU1 & 0.720 & \multirow{7}{*}{0.84} \\
\hline PEU2 & 0.704 & \\
\hline PEU3 & 0.727 & \\
\hline PEU4 & 0.720 & \\
\hline PEU5 & 0.632 & \\
\hline PEU6 & 0.754 & \\
\hline PEU7 & 0.767 & \\
\hline \multicolumn{3}{|l|}{ Perceived Usefulness (PU) } \\
\hline PU1 & 0.661 & \multirow{10}{*}{0.89} \\
\hline PU2 & 0.701 & \\
\hline PU3 & 0.782 & \\
\hline PU4 & 0.768 & \\
\hline PU5 & 0.670 & \\
\hline PU6 & 0.740 & \\
\hline PU7 & 0.640 & \\
\hline PU8 & 0.763 & \\
\hline PU9 & 0.767 & \\
\hline PU10 & 0.631 & \\
\hline \multicolumn{3}{|l|}{ Attitude (A) } \\
\hline A1 & 0.763 & \multirow{5}{*}{0.87} \\
\hline $\mathrm{A} 2$ & 0.853 & \\
\hline A3 & 0.833 & \\
\hline A4 & 0.799 & \\
\hline A5 & 0.796 & \\
\hline \multicolumn{3}{|l|}{ Subjective norm (SN) } \\
\hline SN1 & 0.836 & \multirow{3}{*}{0.87} \\
\hline SN2 & 0.842 & \\
\hline SN3 & 0.763 & \\
\hline \multicolumn{3}{|l|}{ Actual use (AU) } \\
\hline AU1 & 0.803 & \multirow{5}{*}{0.74} \\
\hline AU2 & 0.755 & \\
\hline AU3 & 0.400 & \\
\hline AU4 & 0.789 & \\
\hline AU5 & 0.721 & \\
\hline
\end{tabular}

\subsection{Finding and Discussion}

Path Analysis with STATA version 12 was used to test the hypothesis. To see the effect of Perceived ease of use of computerbased transaction processing system to Perceived Usefulness can be seen in table 3 where there is positive relationship ( $p<0.05)$. It can be concluded that perceived ease of use has a positive effect on perceived usefulness which means that hypothesis 1 is supported. The results show that employees feel that easiness of using computer-based transaction processing system will provide more benefits in using it. The results of this study are supported by several previous studies of $(21,23-26)$. These findings indicate that perceived ease of use powerful its effect on perceived usefulness is indicated by a coefficient larger 0.61 from other researchers.

\section{(See Annexure A)}

The results of path analysis shown in Table 3 provide information that perceived ease of use of computer-based transaction processing system has a positive relationship $(\mathrm{p}<0.05)$ to Attitude. These results are consistent with the results of the study (27) who found that easiness largely determines student attitudes using Computing Resource Center (CRCs) for inexperienced groups. In addition, these results are supported by Bashir (28) found that perceived ease of use had a positive effect on attitude. This indi- 
cates that the ease of use of computer-based transaction processing system is considered by employees as a very good idea.

Table 3. The Result of Path Analysis

\begin{tabular}{|l|l|l|l|}
\hline The Hiyotesis & $\begin{array}{l}\text { Path coef- } \\
\text { ficient }\end{array}$ & $\begin{array}{l}\text { P Val- } \\
\text { ue }\end{array}$ & Support \\
\hline $\begin{array}{l}\text { H1 : Perceived Ease of use } \longrightarrow \text { Perceived } \\
\text { Usefulness }\end{array}$ & 0,61 & 0,000 & Yes \\
\hline $\mathrm{H} 2:$ Perceived Ease of use $\longrightarrow$ Attitude & 0,14 & 0,016 & Yes \\
\hline $\mathrm{H} 3:$ Perceived Usefulness $\longrightarrow$ Attitude & 0,54 & 0,000 & Yes \\
\hline $\mathrm{H} 4:$ Social Infuence $\longrightarrow$ Attitude & 0,27 & 0,000 & Yes \\
\hline $\begin{array}{l}\mathrm{H} 5 ; \text { Attitude Actual } \\
\text { Use }\end{array}$ & 0,53 & 0,000 & Yes \\
\hline
\end{tabular}

For the 3rd hypothesis, research results found that perceived usefulness on attitude has a positive relationship $(p<0.05)$. The results of this study are consistent with the results of (28) found that perceived usefulness had a positive effect on attitude. Similar results were also found in the mobile banking use sevices (29). This research is also consistent with the results of the research of (30-31) These findings also show that perceived usefulness powerful its effect on attitude and simultaneously supports research TAM performed earlier researchers.

The 4th hypothesis states that subjective norm on attitude positive relationship $(\mathrm{p}<0.05)$. The effect of subjective norm on attitude shows that peer opinion support will greatly determine the attitude of employees in the use of the system. These results are supported by the results of the study that found the subjective norms that affect user attitudes (5). So these findings suggest that peer opinion plays an important role for users of computer-based transaction processing system

Hypothesis Testing 5 can be seen with a path coefficient of 0.54 ( $p$ $<0.05$. These results indicate that attitude positively related to actual use. Finally, it can be conclude that the 5th hypothesis is supported. These results are consistent with the results of the study showing the positively influenced attitude toward the use of Massive Open Online Courses (21); and against the use of technological information on Nir Pars Company (32). These findings indicate that a very important user attitude is maintained to positively affect the use of computer-based transaction processing systems

\section{Conclusion and Recommendation}

The purpose of this study is to investigate the determinants of actual use of computer-based transaction processing systems in minimarkets in the city of Padang, Indonesia. Based on the results of this study, it can be concluded that subjective norms, perceived ease of use and perceived usefulness have a positive effect on attitude and actual use. This result recommends to minimarket owners / managers to establish user attitudes by formulating strategies to accelerate actual use of the system. In addition, it is necessary to enhance the role of superior and colleagues in using the system $(6,19)$. This is because the user is more concerned about the support of opinion. Perceived ease of use and perceived usefulness have an effect on attitudes. This suggests that the manager/owner should select an experienced designer to create a transaction processing system. This aims, for the system designed more easily used and able to improve user performance $(4,33)$. If the user feels easy to use transaction processing system, will certainly feel the usefulness of the system and will use the system in the work (20)

These findings provide an understanding of the development of the theory of acceptance of the technology, but in this study using only one external variable. It will be necessary to extend this research in the future by adding external variables, e.g. job relevance (12), perceived behavioral control (17), compatibility (14) and a variety of individual characteristics (e.g. Age, gender, education. Experience) as moderator variable.

\section{Conflict of Interest}

In this study there was no conflict of interest

\section{Acknowledgments}

We are very grateful to the Ministry of Research, Technology and Higher Education. of The Republic of Indonesia for funding this research. We also express our gratitude to the Rector and Chairman of LPPM of Bung Hatta University and his staff for the support given so far.

\section{References}

[1] Mahar, E. F. (2003). Role of Information Technology in Transaction Processing System. Pakistan Journal of Information and Technology, 2(2)

$128-134$ https://doi.org/10.3923/itj.2003.128.134

[2] Vlahos, G. E., Ferratt, T. W., \& Knoepfle, G. (2004). The use of computer-based information systems by German managers to support decision making. Information and Management, 41(6), 763-779. https://doi.org/10.1016/j.im.2003.06.003

[3] Davis, F. (1989). Perceived Usefulness, Perceived Ease Of Use, And User Accep. MIS Quarterly, 13(3), 319. https://doi.org/10.2307/249008

[4] Davis, F. D., Bagozzi, R. P., \& Warshaw, P. R. (1989). User Acceptance of Computer Technology : a Comparison of Two Theoretical Models *. Management Science, 35(8), 982-1003.

[5] Schierz, P. G., Schilke, O., \& Wirtz, B. W. (2010). Understanding consumer acceptance of mobile payment services: An empirical analysis. Electronic Commerce Research and Applications, 9(3), 209-216. https://doi.org/10.1016/j.elerap.2009.07.005

[6] Taylor, S., \& Todd, P. A. (1995b). Understanding information technology usage: A test of competing models. Information Systems Research. https://doi.org/10.1287/isre.6.2.144

[7] Fishbein, M. \& Ajzen, I. (1975). Belief, attitude, attitude, intention and behavior: An introduction to theory of research. Reading, $M A$ : Addison-Wesley Addison-Wesley, 578.

[8] Venkatesh, Viswanath., Davis, F. D. (2000). Theoretical Acceptance Extension Model: Field Four Studies of the Technology Longitudinal. Management Science, 46(2), 186-204. https://doi.org/10.1287/mnsc.46.2.186.11926

[9] Wei, W. C. (2009). A technology acceptance model: Mediate and moderate effect. Asia Pacific Management Review, 14(4), 461-476.

[10] Wallace, L. G., \& Sheetz, S. D. (2014). Information \& Management The adoption of software measures: A technology acceptance model ( TAM ) perspective. Information \& Management, 51(2), 249-259. https://doi.org/10.1016/j.im.2013.12.003

[11] Fathema, N., Shannon, D., \& Ross, M. (2015). Expanding The Technology Acceptance Model ( TAM ) to Examine Faculty Use of Learning Management Systems ( LMSs ) In Higher Education Institutions. MERLOT Journal of Online Learning and Teaching, 11(2), 210-232. https://doi.org/10.12720/joams.4.2.92-97

[12] Venkatesh Viswanath; Bala, H. (2008). Technology Acceptance Model 3 and a Research Agenda on Interventions. Decision Sciences, $39(2), \quad 273-315 . \quad$ https://doi.org/10.1111/j.15405915.2008.00192.x

[13] Natarajan, T., Balasubramanian, S. A., \& Kasilingam, D. L. (2017) Understanding the intention to use mobile shopping applications and its influence on price sensitivity. Journal of Retailing and Consumer Services, 37, 8-22. https://doi.org/10.1016/j.jretconser.2017.02.010

[14] Cheng, Y. M. (2015). Towards an understanding of the factors affecting m-learning acceptance: Roles of technological characteristics and compatibility. Asia Pacific Management Review, 1-11. https://doi.org/10.1016/j.apmrv.2014.12.011

[15] Darsono, L. I. (2005). Examining Information Technology Acceptance by Individual Professionals. Gadjah Mada International Journal of Business, 7(2), 155-178.

[16] Premkumar, G., \& Bhattacherjee, A. (2008). Explaining information technology usage: A test of competing models. Omega, 36, 64-75. https://doi.org/10.1016/j.omega.2005.12.002

[17] Hsu, M. H., \& Chiu, C. M. (2004). Predicting electronic service continuance with a decomposed theory of planned behaviour. Behaviour and Information Technology, 23(5), 359-373. 
https://doi.org/10.1080/01449290410001669969/10.1108/APJML06-2013-0061

[18] Macedo, I. M. (2017). Predicting the acceptance and use of information and communication technology by older adults: An empirical examination of the revised UTAUT2. Computers in Human Behavior, 75. https://doi.org/10.1016/j.chb.2017.06.013

[19] Dwivedi, Y. K., Rana, N. P., Jeyaraj, A., Clement, M., \& Williams, M. D. (2017). Re-examining the Unified Theory of Acceptance and Use of Technology (UTAUT): Towards a Revised Theoretical Model. Information Systems Frontiers, 1-16. https://doi.org/10.1007/s10796-017-9774-y.

[20] Venkatesh, V., Thong, J. Y. L., \& Xu, X. (2012). Consumer Acceptance And Use of Information Technology: Extending The Unified Theory of Acceptance and Use of Technology. Forthcoming in MIS Quarterly, Vol. 36, No. 1 (2012), Pp. 157-178, 36(1), 157-178.

[21] Wu, B., \& Chen, X. (2016). Continuance intention to use MOOCs: Integrating the technology acceptance model (TAM) and task technology fit (TTF) model. Computers in Human Behavior, 67, 221-232. https://doi.org/10.1016/j.chb.2016.10.028

[22] Hair, J. F., Black. W. C., Babin. B. J.; and Anderson. R. E. (2010), Multivariate Data Analysis, 7th ed. Pearson Prentice Hall, New Jersey.

[23] Erasmus, E., Rothmann, S., \& Van Eeden, C. (2015). A structural model of technology acceptance. SA Journal of Industrial Psychology, 41(1), 1-12. https://doi.org/10.4102/sajip.v41i1.1222

[24] Rauniar, R., Rawski, G., Yang, J., \& Johnson, B. (2013) Technology acceptance model ( TAM ) and social media usage : an empirical study on Facebook. https://doi.org/10.1108/JEIM-042012-0011

[25] Giovanis, A. N., Binioris, S., \& Polychronopoulos, G. (2012). An extension of TAM model with IDT and security/privacy risk in the adoption of internet banking services in Greece. EuroMed Journal of Business, 7(1). https://doi.org/10.1108/14502191211225365

[26] Ayeh, J. K. (2015). Travelers acceptance of consumer-generated media: An integrated model of technology acceptance and source credibility theories. Computers in Human Behavior, 48, 173-180. https://doi.org/10.1016/j.chb.2014.12.049

[27] Taylor, S., \& Todd, P. (1995a). Assessing IT Usage: The Role of Prior Experience. MIS Quarterly, 19(4), 561. https://doi.org/10.2307/249633

[28] Bashir, I., \& Madhavaiah, C. (2015). Consumer attitude and behavioral intention towards Internet banking adoption in India. Journal of Indian Business Research, 7(1), 67-102. https://doi.org/10.1108/JIBR-02-2014-0013

[29] Alsamydai, M. J. (2014). Adaptation of the Technology Acceptance Model (TAM) to the Use of Mobile Banking Services. International Review of Management and Business Research, 3(4), 2016-2028. Retrieved from www.irmbrjournal.com

[30] Afshan, S., \& Sharif, A. (2016). Acceptance of mobile banking framework in Pakistan. Telematics and Informatics, 33(2). https://doi.org/10.1016/j.tele.2015.09.005

[31] Chaouali, W., Ben Yahia, I., \& Souiden, N. (2016). The interplay of counter-conformity motivation, social influence, and trust in customers' intention to adopt Internet banking services: The case of an emerging country. Journal of Retailing and Consumer Services, 28, 209-218. https://doi.org/10.1016/j.jretconser.2015.10.007

[32] Moshki, M. K., Teimouri, H., \& Ansari, R. (2013). A Survey on the Level of Organization Agility and Proposition of a Comprehensive Model (the Case of Nir Pars Company). International Journal of Human Resource Studies, 3(3), 62. https://doi.org/10.5296/ijhrs.v3i3.4271

[33] Gao, Lingling and Bai, Xuesong, (2014). A Unified perspective on the factors influencing consumer acceptance of internet of things technology, Asia Pacific Journal of Marketing and Logistics, 26(2), 211 - 231. http://dx.doi.org 


\section{Annexure A}

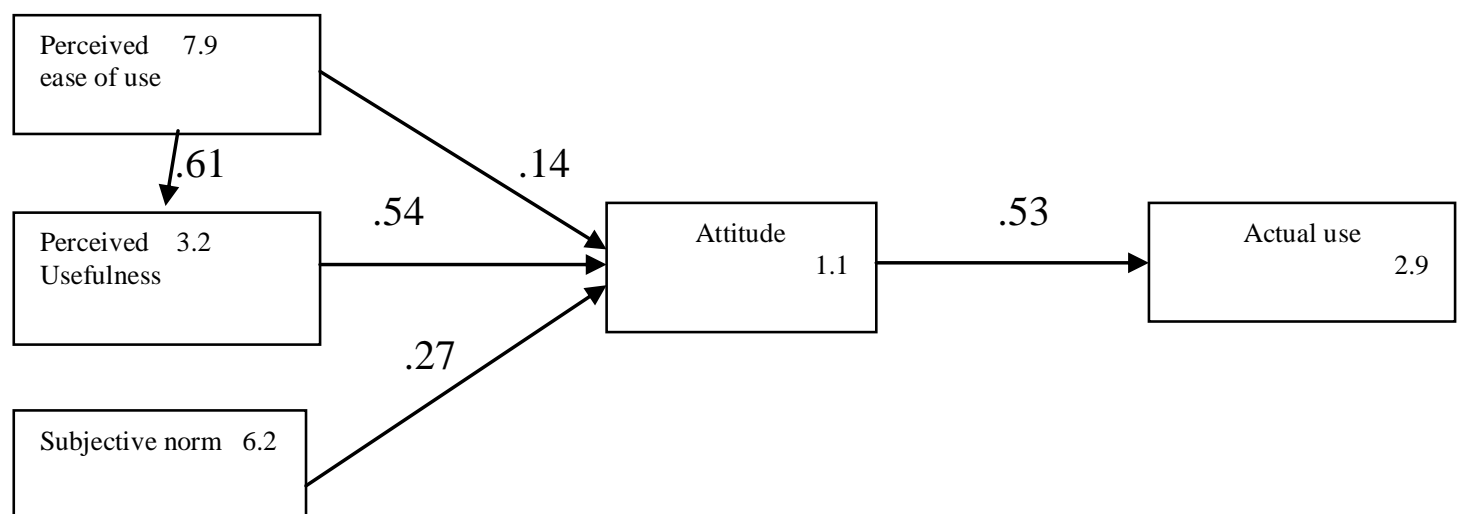

Figure 3. Path Analysis Model 